\title{
New data on spiders (Aranei) from southern part of the Khabarovsk Province
}

\section{Новые данные о пауках (Aranei) юга Хабаровского края}

\author{
Mikhail M. Omelko ${ }^{1,2}$ and Yuri M. Marusik ${ }^{3,4}$ \\ М.М. Омелько ${ }^{1,2}$, Ю.М. Марусик ${ }^{3,4}$
}

\footnotetext{
${ }^{1}$ Gornotaezhnaya Station FEB RAS, Gornotaezhnoe Vil., Ussuriyski Dist., Primorski krai 692533, Russia. E-mail: omelkom@gmail.com

${ }^{2}$ Far Eastern Federal University, Sukhanova, 8, Vladivostok 690950, Russia.

${ }^{3}$ Institute for Biological Problems of the North, RAS, Portovaya Str. 18, Magadan 685000, Russia. E-mail: yurmar@mail.ru

${ }^{4}$ Zoological Museum, University of Turku, FI-20014 Turku, Finland

${ }^{1}$ Горнотаёжная станция им. В.Л. Комарова ДВО РАН, с. Горнотаёжное, Уссурийский район, Приморский край 692533, Россия. Еmail: omelkom@gmail.com

2 Дальневосточный Федеральный университет, Суханова 8, Владивосток, 690950, Россия.

${ }^{3}$ Институт биологических проблем Севера ДВО РАН, Портовая 18, Магадан 685000. E-mail: yurmar@mail.ru
}

KEY WORDS: Far East Asia, new record, Khabarovsk Province

KEY WORDS: Дальний Восток, новая находка, Хабаровский край

ABSTRACT. Material collected from the Ko Mountain (southern part of Khabarovsk Prov.) revealed 58 spider morphospecies. It was found that Ko Mt. is the northernmost locality for 4 species, earlier known only from the Maritime Province and is the northern limit of distribution for the Cybaeidae in continental Asia. In addition the studied locality is the southern limit of distribution for 8 species and one genus (Tanasevitchia Marusik et Saaristo, 1999). Six species, one genus (Cybaeus L. Koch, 1868) and one family (Cybaeidae) are new to the province. Four species are new to science and will be described in revisional works.

ABSTRACT. На основе материала собранного на горе Ко (юг Хабаровского края) было выявлено 58 морфовидов пауков. Показано, что гора Ко является самой северной точкой для 4 видов ранее известных только из Приморского края, а также для семейства Cybaeidae в континентальной Азии. Изученная вершина является также самой южной точкой ареала в распространении 8 видов и одного рода (Tanasevitchia Marusik et Saaristo, 1999). Шесть видов, один род (Cybaeus L. Koch, 1868) и одно семейство (Cybaeidae) являются новыми для Хабаровского края. Четыре вида новые для науки и будут описаны в обзорных работах.

\section{Introduction}

Spiders in the Khabarovsk Province have been unevenly studied. The more-completely studied areas include two reserves, the Bolshekhekhtsyrski and the Bureinski, for which there are detailed check-lists for all families [Trilikauskas, 2006; Marusik et al., 2007].
The Linyphiidae have been well surveyed within the Norsky Reserve [Tanasevitch, 2005] and some localities along the Amur River valley have been briefly studied [cf. Kim, Kurenshchikov, 1995]. About hundred species are known from the northern part of the province, along the shore of the Sea of Okhotsk [Marusik, 2005]. The southernmost parts of the Khabarovsk Province adjacent to the Maritime Province remain almost unstudied: only 17 species are known from Bikinski District and none from the others. In 2013 the senior author had opportunity to visit the Ko Mountain located in the south-eastern part of the Imeni Lazo District and to collect spiders in the foothills and on the mountain. The main goals of this paper are to comment upon the most interesting records and to describe the distribution of species along an altitudinal transect.

\section{Material and methods}

All spiders were collected by the senior author in the Ko Mt. $\left(47^{\circ} 6^{\prime} \mathrm{N} 136^{\circ} 33^{\prime} \mathrm{E}\right.$, southern part of the Khabarovsk Province, Imeni Lazo District) in June 17-27, 2013. Material was collected chiefly by pitfall trapping and some by hand picking. Material was collected in the following habitats: 1) Forbs along the forest (from mixed to coniferous) road with some screes (550-1400 m), 2) Birch-woods (1400-1650 m) (Photo 1), 3) Mountain tundra (1700-1850 m) with screes (Photo 2) and with shrub vegetation (Rhododendron, Pinus pumila, etc., Photo 3). Screes are present in all three belts, but most common on the upper elevations.

Three marks were used to show distribution limits of some species: ${ }^{*}$ southernmost locality in the range; ${ }^{\wedge}$ 


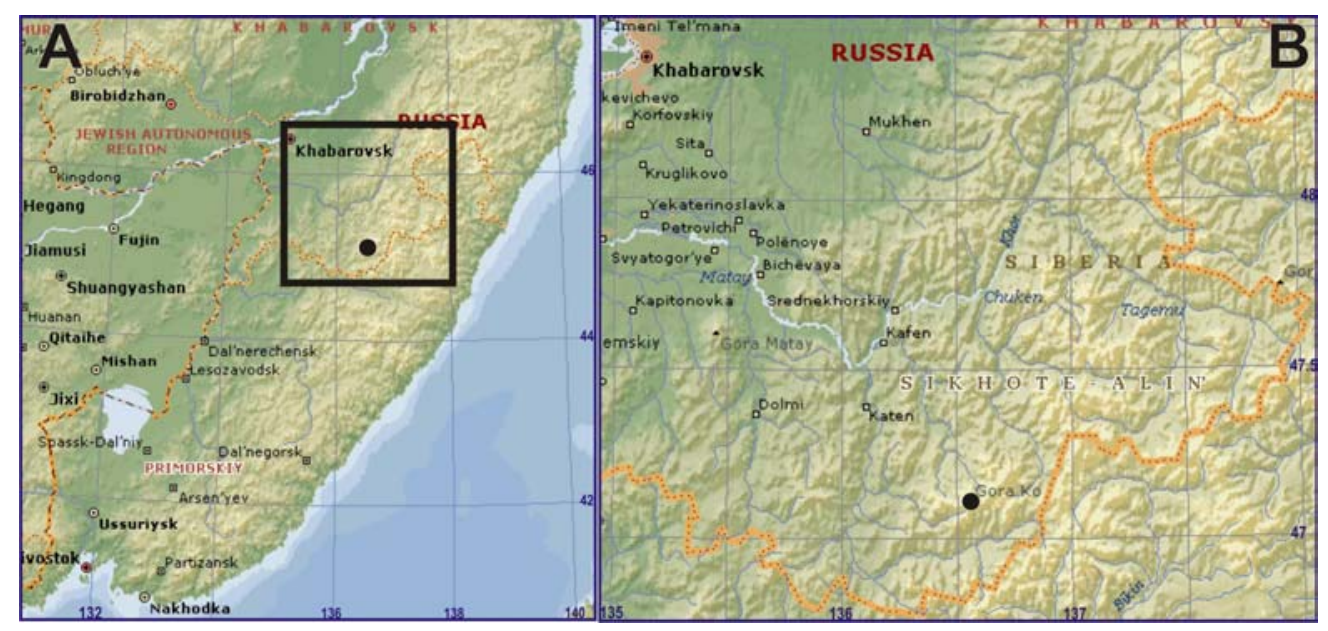

Map 1. A - Maritime and south part of the Khabarovsk Provinces; B - close up of south Part of Khabarovsk Province. Dot indicates position of the Ko Mt.

Карта 1. А - Приморский край и юг Хабаровского края; В - участок южной части Хабаровского края. Гора Ко показана точкой.
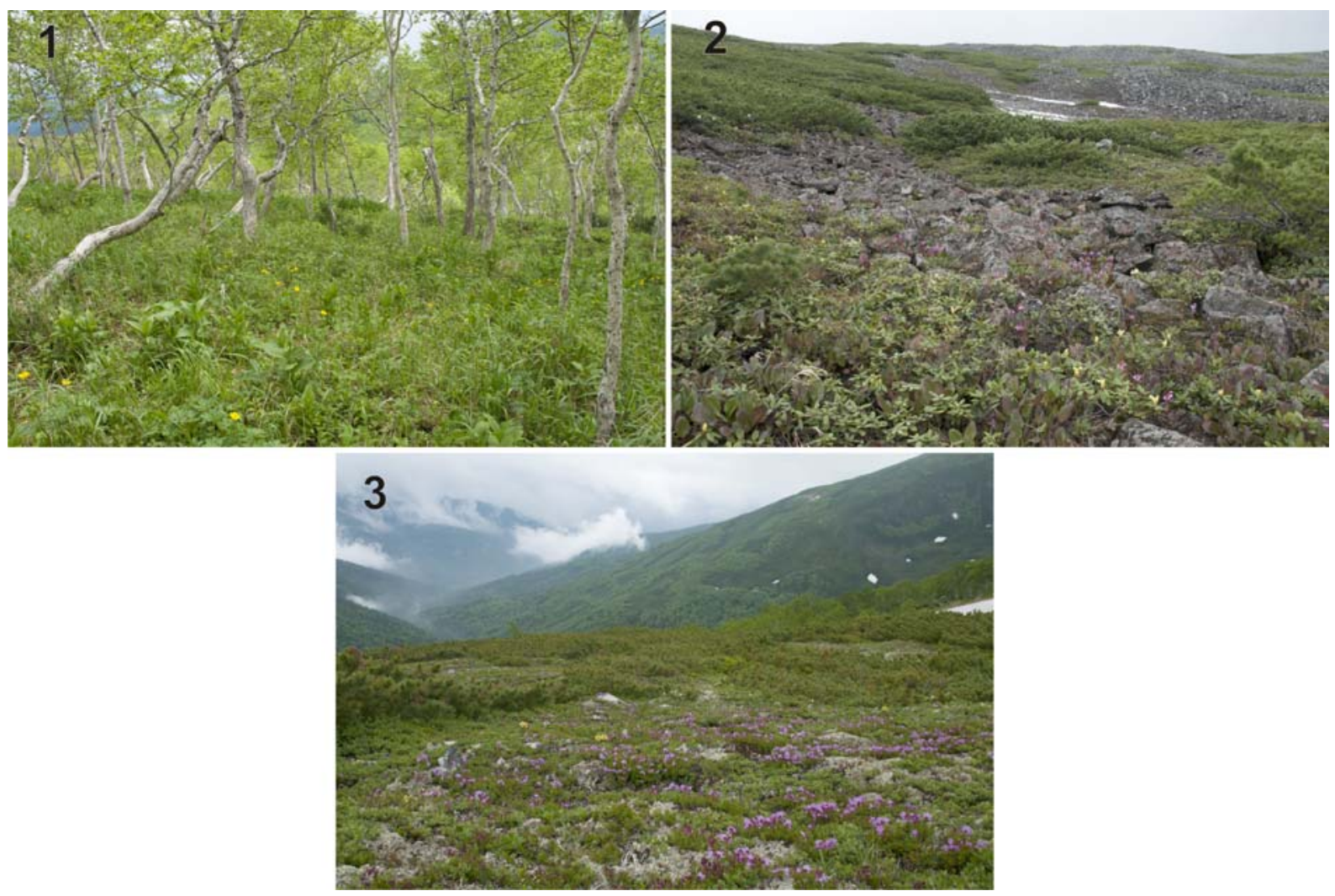

Photos 1-3. Habitats in the Ko Mt.

1 - birchwood; 2 - mountain screes in mountain tunda; 3 - mountain tundra.

Фото 1-3. Местообитания на горе Ко.

1 - высокогорные березняки; 2 - каменистые осыпи в зоне горных тундр; 3 - горная тундра. 
northernmost locality in the range; ${ }^{\mathrm{n}}$ new for the province.

\section{Species survey}

\section{Family ARANEIDAE}

\section{Aculepeira sp.}

Comments. This species closely resembles $A$. matsudae Tanikawa, 1994 known only from the highlands of Hokkaido. Most probably it represents a new species. A female that is likely to belong to the same species has been reported from the Lazo Reserve [Oliger et al., 2002]. For certain identification it will be important to make comparisons with Japanese specimens and we intend to carry out such a study in the future.

\section{Family CYBAEIDAE ${ }^{\wedge n}$}

Comments. This record of Cybaeus sp. from the Ko Mt. is the northernmost record for the genus and entire family for the continental part of Asia. The northern limit of the range in Asia overall lies about $2^{\circ}$ latitude further to the north within Sakhalin Island [Marusik, Logunov, 1991] than in the Khabarovsk Province. This is the first record for this family from the Khabarovsk Province.

\section{Cybaeus aff. confrantis Oliger, $1994^{\wedge \mathrm{n}}$}

Comments. This is a new species which will be described in a special revision of the genus [Omelko, Marusik, in preparation].

\section{Family GNAPHOSIDAE}

Gnaphosa sticta Kulczyński, 1908

Comments. This is a North-Euro - Siberian species known south to the Maritime Province (Gorelaya Sopka Mt.) [Marusik, Koponen, 2000]. Within the Khabarovsk Province it has previously been recorded from the $\mathrm{Bu}-$ reinski Reserve [Trilikauskas, 2008a] and our record is therefore the southernmost for the province.

\section{Micaria aenea Thorell, 1871*}

Comments. This species has a circum-Holarctic range and is restricted to the boreal zone, and to hypoarctic and alpine communities. Within the Khabarovsk Province it has been recorded only from the Bureinski Reserve [Trilikauskas, 2008a]. The current record is the southernmost in the Palaearctic.

\section{Micaria alpina L. Koch, 1872*}

Comments. This species has a circum-Holarctic range and is restricted to the boreal zone, and to hypoarctic and alpine communities. Within the Khabarovsk Province it has been recorded from the Bureinski Reserve [Trilikauskas, 2008b] and the southern part of the Khabarovsk Province (unspecified locality) $[\mathrm{Ku}-$ renshchikov, 1999]. The current record is the southernmost in the Palaearctic.

\section{Zelotes puritanus Chamberlin, 1922*}

Comments. This species has a circum-Holarctic range and is restricted to the boreal and nemoral zones and to alpine communities. Within the Khabarovsk Province it has previously been recorded from the $\mathrm{Bu}-$ reinski Reserve [Trilikauskas, 2008b]. The current record is the southernmost in the Palaearctic.

Zelotes sula Lowrie et Gertsch, $1955^{* n}$

Comments. This species has a Siberio-Nearctic range and is restricted to the boreal zone. It was previously unknown from the Khabarovsk Province and the current record is the southernmost in the Palaearctic.

\section{Family LINYPHIIDAE}

Tanasevitchia Marusik et Saaristo, 1999*

Comments. This is a small genus with only two species [Platnick, 2014]. Both occur in Siberia only. One species, T. strandi (Ermolaev, 1937) is restricted to Altai [Tanasevitch, 2008]. Another species is commented below.

\section{Tanasevitchia uralensis (Tanasevitch, 1983)*}

Figs 1-12.

Comments. This species has a Siberian range and is restricted to boreal and hypoarctic zones. Earlier this species and genus was recorded from about $52^{\circ} \mathrm{N}$ to the south [cf. Tanasevitch, 2008]. The current record is the southernmost in its range and extends the distribution of the species and genus about $6^{\circ}$ of latitude to the south.

Because the somatic characters and the fine of structural details of the male palp and epigyne (median plate) were never properly illustrated we present here digital and SEM photographs showing the unusual shape of the male carapace (Figs. 1-2, 4-5); the very long cymbium (longer than tibia (Fig. 1) divided at its posterior end (Figs 3, 5, 7); the shape of the embolic division (Fig. 8) and the median plate of the epigyne (Fig. 10); the male leg I lacking tibial spines (Fig. 11) and the female leg I with spines (Fig. 12).

\section{Family LYCOSIDAE}

Acantholycosa aborigenica Zyuzin et Marusik, 1988

Comments. This species has previously been recorded from the northern part of the province [Trilikauskas, 2008a] and it is known from several localities in the Maritime Province [Marusik et al., 2003].

Alopecosa cf. aculeata (Clerck, 1757)

Comments. This is a new species which will be described in a special revision. We know this species from one locality in the northern part of Maritime Province.

Alopecosa hokkaidensis Tanaka, 1985

Comments. This species has previously been recorded within Russia from the Maritime Province 


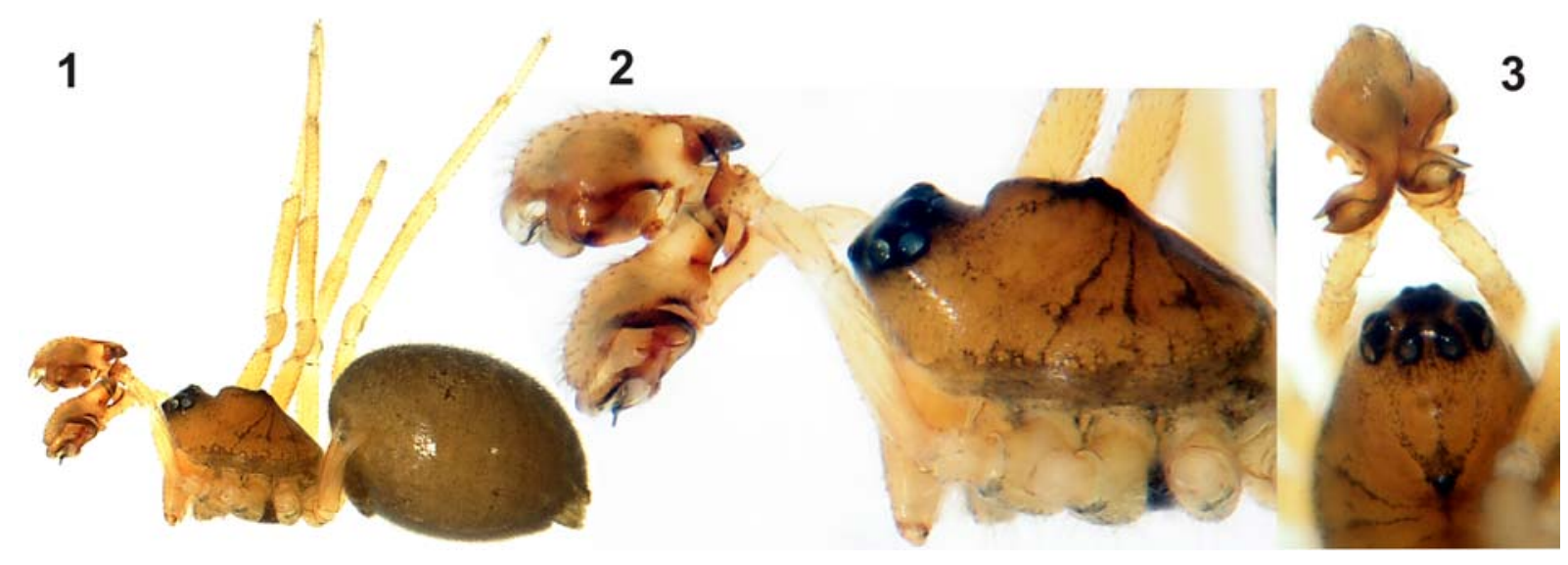

Figs 1-3. Male of Tanasevitchia uralensis. 1 - habitus, lateral; 2 - prosoma, lateral; 3 - prosoma, dorsal.

Рис. 1-3. Самец Tanasevitchia uralensis. 1 - внешний вид, латерально; 2 - головогрудь, латерально; 3 - головогрудь, дорзально.

[Marusik, Koponen, 2000] and Khabarovsk Province: Bolshekhekhtsyrskiy Reserve [Marusik et al., 2007]. It also occurs in northeastern China and Hokkaido.

Alopecosa moriutii Tanaka, 1985^n

Comments. This species has previously been recorded within Russia only from the Maritime Province [Marusik, Koponen, 2000]. It also occurs in Korea and Japan. The current record is first for the province and is the northernmost of its entire range.

Pardosa eiseni (Thorell, 1875)

Comments. It has a trans-Palearctic range and is restricted to boreal and hypoarctic zones. Within the Khabarovsk Province it has been recorded only from the Bureinski Reserve [Trilikauskas, 2008a].

\section{Pardosa lyrata (Odenwall, 1901)}

Comments. It has a Siberian range and is restricted to the boreal zone. Within the Khabarovsk Province has been recorded only from the Bureinski Reserve [Trilikauskas, 2008a].

Pardosa nordicolens Chamberlin et Ivie, 1947*

Comments. It has an East-Siberian - Northwest Nearctic range. Asian records are from the boreal zone, while most of Nearctic records are from the tundra [Dondale, Redner, 1990]. Within the Khabarovsk Province has been recorded only from the Bureinski Reserve [Trilikauskas, 2008a]. The current record is the southernmost of its entire range.

"Sibirocosa" sp.

Comments. This is a new species belonging to an undescribed genus related to Sibirocosa Marusik, Azarkina et Koponen, 2003 and will be described in a separate paper.

\section{Family SALTICIDAE}

Chalcoscirtus tanyae Logunov et Marusik, 1999^n

Comments. Previously this species has been recorded from two localities in the Maritime Province [Logunov, Marusik, 2000]. The new record extends known range over $3^{\circ}$ to the North and represent the first record of the species in the Khabarovsk Province.

\section{Family THOMISIDAE}

\section{Xysticus luctuosus (Blackwall, 1836)*n}

Comments. It has a circum-Holarctic range and is restricted to boreal and nemoral zones [Marusik et al., 2000]. This is the first record of this species from the Khabarovsk Province and is the southernmost for Asia.

Xysticus rugosus Buckle et Redner, 1964*

Comments. It has a Siberian - West Nearctic range and occurs among stones [Marusik et al., 2000]. Within the Khabarovsk Province it has previously been recorded only from the Bureinski Reserve [Trilikauskas, 2008b]. This current record is the southernmost in its entire range.

\section{Discussion}

Because material was collected during a short period and chiefly by pitfall traps it is impossible to make any detailed analysis of altitudinal distribution. However some conclusions can be made, especially in respect to the wandering species. Most of the species (48) were collected from lower elevations. The number of species found in the birch-woods and mountain tundra were almost the same (10 and 13, respectively). Only two species, Acantholycosa norvegica and "Sibiricosa" sp., were found through the whole transect. Both are restricted to scree habitats. Two species, Evarcha proszynskii and Pardosa cf. lugubris, are common 

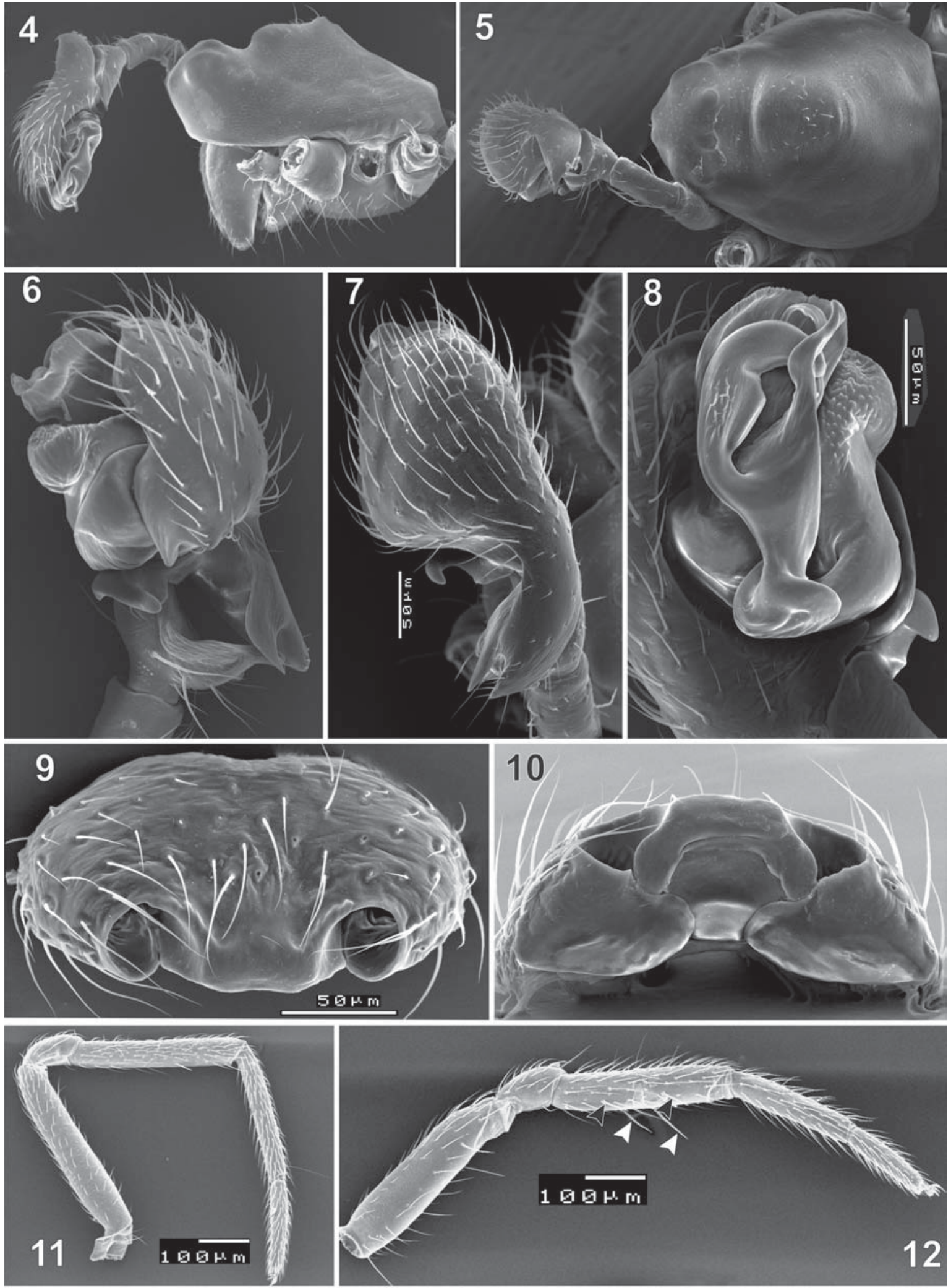

Figs 4-12. Tanasevitchia uralensis. 4-5 - male, prosoma lateral and dorsal; 6-8 - male palp, retrolateral, dorsal and prolateral; 910 - epigyne, ventral and caudal; 11 - male, leg I; 12 - female, leg I (arrows indicate tibial spines).

Рис. 4-12. Tanasevitchia uralensis. 4-5 - самец, головогрудь латерально и дорзально; 6-8 - пальпа самца, ретролатерально, дорзально и пролатерально; 9-10 - эпигина, вентрально и каудально; 11 - самец, нога I; 12 - самка, нога I (стрелки показывают шипы голени). 
Table 1. Material collected and distribution of spiders among three altitudinal belts in the Ko Mt. Табл. 1. Исследованный материал и распространение пауков по трем высотным поясам в на горе Ко.

\begin{tabular}{|c|c|c|c|}
\hline Species $\backslash$ Elevation, $\mathrm{m}$ & $550-1400$ & $1400-1650$ & $1700-1850$ \\
\hline Araneidae & & & \\
\hline Aculepeira sp. & & & $10^{7}$ \\
\hline Hypsosinga sanquinea (C.L. Koch, 1844) & $20^{7}+$ & & \\
\hline Larinioides cornutus (Clerck, 1757) & $10^{7}$ & & \\
\hline Clubionidae & & & \\
\hline Clubiona irinae Mikhailov, 1991 & $20^{7} \sigma^{7}$ & & \\
\hline Clubiona kulczynskii Lessert, 1905 & $10^{7}$ & & \\
\hline Clubiona sp. & $10^{7}$ & & \\
\hline Cybaeidae & & & \\
\hline Cybaeus sp. aff. confrantis Oliger, 1994 & $10^{T}$ & & \\
\hline Gnaphosidae & & & \\
\hline Callilepis schuszteri (Herman, 1879) & $60^{\top} \sigma^{\top} 1+$ & & \\
\hline Drassodes cupreus (Blackwall, 1834) & $20^{7} \sigma^{7}$ & $10^{7}$ & \\
\hline Gnaphosa sticta Kulczyński, 1908 & $47 \sigma^{\top} \sigma^{\top} 1+$ 운 & $20^{\top} \sigma^{\top}$ & \\
\hline Micaria aenea Thorell, 1871 & $10^{\top} 3+9$ & & \\
\hline Micaria alpina L. Koch, 1872 & $10^{7} 2$ 우 & & \\
\hline Micaria pulicaria (Sundevall, 1831) & $20^{7}+$ & & \\
\hline Zelotes puritanus Chamberlin, 1922 & $20^{\top} \sigma^{\top} 2$ 2 +9 & & \\
\hline Zelotes sula Lowrie et Gertsch, 1955 & $10^{T}$ & & \\
\hline Linyphiidae & & & \\
\hline Agyneta olivacea (Emerton, 1882) & $40^{7} 0^{x}$ & & \\
\hline Agyneta sp. & & $30^{7} \sigma^{7} 1$ 우 & \\
\hline Asperthorax borealis Ono et H. Saito, 2001 & $10^{x}$ & & \\
\hline Bathyphantes eumenis (L. Koch, 1879) & $1+$ & & \\
\hline Collinsia sp. & $40^{7} 0^{7}$ & & \\
\hline Dicymbium yaginumai Eskov et Marusik, 1994 & $50^{7} 0^{7}$ & & \\
\hline Diplocephalus sp. & $10^{T}$ & & \\
\hline Erigoninae gen. 1 sp. 1 & $10^{T}$ & & \\
\hline Erigoninae gen. 2 sp. 1 & $30^{x} \sigma^{x}$ & & \\
\hline Erigoninae gen. 3 sp. 1 & & $10^{7}$ & \\
\hline Lasiargus sp. & $10^{7}$ & & \\
\hline Micrargus herbigradus (Blackwall, 1854) & $10^{T}$ & & \\
\hline Nippononeta sp. & $\sigma^{\top} \sigma^{2}+0$ & & \\
\hline Pocadicnemis pumila (Blackwall, 1841) & $70^{7}+$ & & \\
\hline Tanasevitchia uralensis (Tanasevitch, 1983) & $10^{7}$ & $20^{7}+$ & \\
\hline Walckenaeria $\mathrm{sp} .1$ & 1 우 & & \\
\hline Walckenaeria sp.2 & & 19 & \\
\hline Lycosidae & & & \\
\hline Acantholycosa aborigenica Zyuzin et Marusik, 1988 & $70^{\top} 0^{\top} 2+90$ & $30^{7} 0^{7} 1$ 1 & \\
\hline Acantholycosa lignaria (Clerck, 1757) & $10^{\pi}$ & $1 \sigma^{7}$ & \\
\hline Acantholycosa norvegica (Thorell, 1872) & $20^{7} 0^{7}$ & $4 \sigma^{\top} \sigma^{\top}$ & $70^{7} 0^{\top} 4$ 우우 \\
\hline Alopecosa aculeata (Clerck, 1757) & $60^{\top} \sigma^{\top} 1+$ & & \\
\hline Alopecosa cf. aculeata (Clerck, 1757) & & & 1 우 \\
\hline Alopecosa hokkaidensis Tanaka, 1985 & & & $120^{\top} 0^{\top} 3$ 우 \\
\hline Alopecosa moriutii Tanaka, 1985 & $100^{\top} 0^{\top} 3$ ? +9 & $90^{\top}+$ & \\
\hline Pardosa cf. lugubris (Walckenaer, 1802) & $630^{\top} \sigma^{\top} 9$ 9 +9 & & $20^{7} \sigma^{x}$ \\
\hline Pardosa eiseni (Thorell, 1875) & & $390^{7}+$ & $4 \bigcirc^{\top} \sigma^{\top} 13$ 13ㅇ \\
\hline Pardosa lyrata (Odenwall, 1901) & $10^{7}$ & & \\
\hline
\end{tabular}


Table 1 (contituing)

Таблица 1 (продолжение)

\begin{tabular}{|c|c|c|c|}
\hline Species $\backslash$ Elevation, $\mathrm{m}$ & $550-1400$ & $1400-1650$ & $1700-1850$ \\
\hline $\begin{array}{l}\text { Lycosidae } \\
\text { Pardosa nordicolens Chamberlin et Ivie, } 1947 \\
\text { Pardosa plumipes (Thorell, 1875) } \\
\text { Pardosa riparia (C.L. Koch, 1833) } \\
\text { "Sibirocosa" sp. } \\
\text { Xerolycosa nemoralis (Westring, 1861) } \\
\text { Phrurolithidae } \\
\text { Phrurolithus festivus (C.L. Koch, 1835) } \\
\text { Salticidae } \\
\text { Chalcoscirtus tanyae Logunov et Marusik, } 1999 \\
\text { Evarcha proszynskii Logunov, Cutler et Marusik, } 1993 \\
\text { Pellenes ignifrons (Grube, 1861) } \\
\text { Tetragnathidae } \\
\text { Pachygnatha listeri Sundevall, 1830 } \\
\text { Thomisidae } \\
\text { Ozyptila sincera Kulczyński, 1926 } \\
\text { Xysticus lepnevae Utotchkin, 1968 } \\
\text { Xysticus luctuosus (Blackwall, 1836) } \\
\text { Xysticus rugosus Buckle et Redner, 1964 } \\
\text { Zoridae } \\
\text { Zora sp. } 1 \\
\text { Zora sp.2 }\end{array}$ & 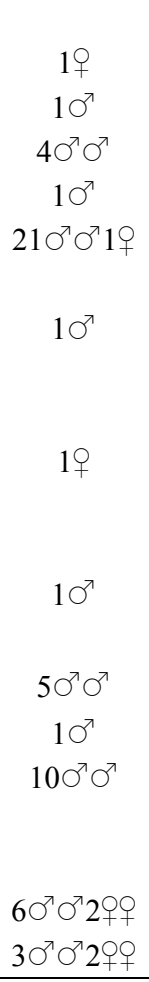 & $10^{7}$ & $\begin{array}{c}30^{7} O^{7} 2 \text { 우 } \\
10^{x} \\
1+\end{array}$ \\
\hline Total & 48 & 10 & 13 \\
\hline
\end{tabular}

for both lower and higher belts and absent from the birch-wood belt. One species was common to the birchwoods and mountain tundra, Pardosa eiseni. Five species were common in lower altitudes and birch-woods. There was little faunal similarity between neighboring birch-woods and mountain tundra belts and this could be because of striking differences between their physical habitats. In mountain tundra most of species are connected with stony screes.

Among the 58 morphospecies found in the Ko Mt. we do not know taxonomic status (not identified to species level) and/or distribution of 12 species. Of the 46 remaining species 10 are endemic to either the SE part of the Palaearctic or to the Maritime and Khabarovsk Provinces. It is most likely that the majority of the unidentified species are also endemics of the SE Palaearctic. Thus, about $1 / 3$ of species collected in the studied area are likely endemic, which is a rather high proportion. Among the 10 endemic species whose range we know, seven occur in the mountain tundra. Considering that only 13 species were found there, the endemism in mountain tundra may be over $50 \%$. Half of these endemic species belongs to the Lycosidae.

ACKNOWLEDGEMENTS. We thank Mikhail M. Omelko (Senior) for his help during the expedition to the Ko Mt. We are grateful to Seppo Koponen who arranged our stay in Zoological Museum, University of Turku. Kirill
Mikhailov helped us with information regarding distribution records of several species in the Khabarovsk Province and adjacent areas. English of the final draft was kindly checked and edited by David J. Court (Singapore). This project was supported in part by the Russian Foundation for Fundamental Research (grant \# 12-04-01548). We also thank to Far Eastern Federal University for the financial assistance allocated during the program "motivation".

\section{References}

Dondale C.D., Redner J.H. 1990. The insects and arachnids of Canada, Part 17. The wolf spiders, nurseryweb spiders, and lynx spiders of Canada and Alaska, Araneae: Lycosidae, Pisauridae, and Oxyopidae // Research Branch, Agriculture Canada, Publ. No.1856. 383 pp.

Kim J.P., Kurenshchikov D.K. 1995. Preliminary spider species list of Khabarovsk Territory Southern part // Korean Arachnol. Vol.11. No.1. P.55-72.

Kurenshchikov D.K. [1999. Spiders (Arachnida, Aranei) in south part of Khabarovsk province. Fauna, ecology, zoogeography]. Abstract of PhD thesis. Tomsk. 23 pp. [in Russian].

Logunov D.V., Marusik Yu.M. 2000. Catalogue of the jumping spiders of northern Asia (Arachnida, Araneae, Salticidae). Moscow: KMK Scientific Press Ltd. 299 pp.

Marusik Yu.M. 2005. [Arachnids (Arachnida: Aranei, Opiliones) of northern Cisokhotia] // Euroasian Entomological Journal. Vol.4. No.3. P.187-208 [in Russian, with English summary].

Marusik Yu.M., Azarkina G.N., Koponen S. 2004. A survey of East Palaearctic Lycosidae (Aranei). II. Genus Acantholycosa Dahl, 1908 and related new genera // Arthropoda Selecta. Vol.12 (for 2003). No.2. P.101-148. 
Marusik Yu.M., Koponen S. 2000. New data on spiders (Aranei) from the Maritime Province // Arthropoda Selecta. Vol.9. No.1. P.55-68.

Marusik Yu.M., Logunov D.V. 1991. [Spiders of the superfamily Amaurobioidea (Aranei) from Sakhalin and Kurily Islands] // Zool. Zhurnal. Vol.70. No.9. P.87-94 [in Russian, with English summary].

Marusik Yu.M., Logunov D.V., Koponen S. 2000. Spiders of Tuva, South Siberia. Magadan: IBPN FEB RAS. 252 pp.

Marusik Yu.M., Tanasevitch A.V., Kurenshchikov D.K., Logunov D.V. 2007. A check-list of the spiders (Araneae) of the Bolshekhekhtsyrski Nature Reserve, Khabarovsk Province, the Russian Far East // Acta Arachnologica Sinica. Vol.16. No.1. P.37-64.

Oliger T.I., Marusik Yu.M., Koponen S. 2002. New and interesting records of spiders (Araneae) from the Maritime Province of Russia // Acta Arachnologica. Vol.51. No.2. P.93-98.

Platnick N.I. 2013. The world spider catalog, version 14.0. American Museum of Natural History; online at: ttp://research.amnh. org/entomology/spiders/catalog/index.html (accessed January 20, 2014).

Tanasevitch 2005. Linyphiid spiders of the Norsky Nature Reserve, Amurskaya Area, Russian Far East (Arachnida, Aranei) // Arthropoda Selecta. Vol.14. No.4. P.347-371.
Tanasevitch A.V. 2008. New records of linyphiid spiders from Russia, with taxonomic and nomenclatural notes (Aranei: Linyphiidae) // Arthropoda Selecta. Vol.16 (for 2007). No.2. P.115-135.

Trilikauskas L. 2006. [On gnaphosid fauna of the Bureya River upper reaches] // Entomologicheskie issledovaniya v Severnoi Azii. Materialy 7-go mezhregional'nogo soveshchaniya entomologov Sibiri i Dal'nego Vostoka v ramkakh Sibirskoi zoologicheskoi konferentsii, Novosibirsk, 20-24 Sent. 2006 g. Novosibirsk. P.147-148 [in Russian].

Trilikauskas L. 2008a. [The composition and structure of the spider fauna of stony screes of the Bureya River (Northern Cisamuria)] // Bioraznoobrazie, problemy ekologii Gornogo Altaya i sopredel'nykh regionov: nastoyashchee, proshloe, budushchee. Materialy Mezhdunarodnoi konferentsii, 22-26 Sent. 2008 g., g. Gorno-Altaisk. Gorno-Altaisk. Part 1. P. 189-194 [in Russian].

Trilikauskas L. 2008b. [Fauna and ecology of spiders in the upper reaches of Bureya River]. Abstract of $\mathrm{PhD}$ thesis. Novosibirsk. 26 pp. [in Russian]

Responsible editor S. Koponen 